\title{
HIV AND SERUM PROTEIN ELECTROPHORESIS PATTERNS IN KWAZULU- NATAL: A RETROSPECTIVE STUDY
}

\author{
N Tathiah, BSc (Hons), $M B C h B$, Dip HIV Med, $M S$ \\ Department of Public Health Medicine, University of KwaZulu-Natal, Durban \\ R Parboosing, $M B C h B, F C P a t h$ (Virol) $S A$, MMed (Virol), $M S$ \\ Department of Virology, National Health Laboratory Service/University of KwaZulu-Natal \\ D Pudifin, $M B C h B, F C P(S A)$, $F R C P$ \\ Department of Medicine, University of KwaZulu-Natal \\ S Mahabeer, MB ChB (Hons), LRCSI, LRCPI, MMed, FRNZCGP \\ Lancet Laboratories, Durban
}

Objective. To describe the effect of HIV serostatus on serum proteins, serum protein electrophoresis (SPEP) patterns and monoclonal bands.

Setting. Inkosi Albert Luthuli Central Hospital, Durban.

Design. Retrospective, anonymous analysis of routine laboratory results.

Results. Monoclonal bands were not increased in HIV-positive patients, who were younger and had increased polyclonal and oligoclonal bands and total proteins when compared with HIV-negative patients.

The hallmark of HIV infection is impairment and dysregulation of the immune system. Specific defects in the humoral arm of the immune system, such as polyclonal activation of $B$ cells, have been widely described in HIV infection. An increased incidence of plasma cell disorders, such as benign polyclonal gammopathy, monoclonal gammopathy, oligoclonal gammopathy, B-cell lymphomas and multiple myeloma, has also been reported in HIV-positive individuals. These abnormalities occur at a significantly younger age (mean 33 years) than in HIV-negative patients.

Hyperactivated B cells secrete HIV-specific and nonspecific antibodies. Serum protein plectrophoresis (SPEP) is a technique that separates proteins on the basis of their electrical charge in order to determine specific patterns in certain diseases. HIV and other infections may have an influence on serum electrophoresis patterns. There may also be ethnic and racial differences in the effects of HIV on immunoglobulin production. ${ }^{1}$ The prevalence of monoclonal gammopathies, for example, is significantly different between racial groups. ${ }^{2}$ Immunoglobulin levels may also vary depending on differing risk behaviours. ${ }^{1}$ There is also controversy regarding the association between HIV infection and multiple myeloma. Some studies have documented an increased risk (approximately 4.5 -fold) of multiple myeloma in HIV/AIDS patients, ${ }^{3,4}$ while other studies have not. ${ }^{5}$
Previous studies in South Africa have not shown a link between multiple myeloma and HIV infection. ${ }^{3,4,6}$ However, the diagnosis of myeloma may be difficult or delayed in HIV-positive patients because features such as anaemia and recurrent bacterial infections occur both in multiple myeloma and HIV infection. ${ }^{5}$

The hallmark laboratory feature of multiple myeloma is the presence of monoclonal bands on SPEP, although these bands may appear with other conditions. The aims of this study were to determine whether there was a higher prevalence of monoclonal bands in HIVpositive patients and to describe differences in serum protein concentrations and electrophoresis patterns in HIV-positive and HIV-negative patients in KwaZulu-Natal province.

\section{METHODS}

This retrospective anonymous database study utilised results of routine tests conducted at Inkosi Albert Luthuli Central Hospital, Durban. All patients who had SPEP performed at this hospital during 2006 were entered into the study. Approximately $20 \%$ of these patients had clinically suspected haematological malignancies. Serum protein levels, electrophoresis patterns, basic demographic data and HIV enzyme-linked immunosorbent assay (ELISA) results were downloaded anonymously and compared and described in HIV-positive and negative patients. Patients without HIV results were excluded. The chi-square test and Fisher's exact test were used for 
the comparison of categorical data, and Student's $t$-test for the comparison of continuous variables. Statistical analysis was performed on STATA ${ }^{\text {TM } 10}$ (StataCorp, Texas, USA). The study was approved by the Biomedical Research Ethics Committee of the Nelson R Mandela School of Medicine, University of KwaZulu-Natal.

\section{Results are set out in Table I. \\ RESULTS}

\section{DISCUSSION}

HIV-positive patients in whom electrophoretograms were performed were significantly younger than those who were HIV negative. These data are similar to those of other studies, in which indications for SPEP occur in HIV-positive individuals at a significantly younger age (mean 33 years) than in HIV-negative patients. ${ }^{3}$

The serum protein abnormalities and SPEP patterns concur with other studies in HIV-positive individuals. ${ }^{7}$ The increase in total proteins in HIV-positive individuals may be due to the increase in the $\mathrm{lg} \mathrm{G}$ fraction of the gamma globulins. This is likely to be caused by hyperactivation of $B$ cells due to chronic antigenic stimulation by antigens of HIV, viruses such as hepatitis $C$, or other opportunistic infections. Polyclonal gammopathy and oligoclonal bands were significantly increased in HIVpositive patients. The majority of oligoclonal bands were present on a background of polyclonal gammopathy, suggesting simultaneous polyclonal B-cell activation and selective B-cell oligoclonal proliferation. The pathologist interpreting the electrophoretograms in this scenario should repeat the SPEP, with dilutions, to minimise the interference of the background polyclonal gammopathy. Immune paresis, which results from the suppression of normal globulins due to the uncontrolled proliferation of the clone causing the B-cell malignancy, was, as expected, higher in the HIV-negative group.

The prevalence of monoclonal bands in HIV-positive patients was $8 \%$, which is higher than previously described (2.5\%); estimates of the prevalence of monoclonal bands, however, vary widely. There was no statistical difference in the prevalence of monoclonal gammopathy between the HIV-seronegative and positive groups. However, it is possible that monoclonal bands in HIV-positive patients may be obscured by the background polyclonal gammopathy. The absence of a monoclonal spike therefore does not altogether exclude the possibility of a monoclonal plasma cell disorder in HIV-positive patients.

This study is biased because only patients who had indications for both SPEP and HIV tests were included. However, multiple myeloma and SPEP abnormalities are likely to be even less prevalent in patients who have no indications for either of these tests. The conclusion of this study, that monoclonal bands are not significantly increased in HIV-positive patients, is therefore valid despite this bias.

\section{CONCLUSION}

HIV-positive patients often succumb to opportunistic infections and other malignancies at a relatively young age. With the roll-out of antiretroviral therapy in South Africa, the incidence of multiple myeloma and other

\section{TABLE I. AGE, PROTEIN LEVELS AND SPEP FINDINGS IN HIV-POSITIVE AND NEGATIVE PATIENTS (N=331)}

\begin{tabular}{|c|c|c|c|}
\hline & HIV seropositive & HIV seronegative & $p$-value \\
\hline$N$ & 102 & 229 & \\
\hline Age (yrs) & $37.0(33.3-40.8)$ & $47.1(44.7-49.5)$ & $<0.00001^{*}$ \\
\hline Albumin $(\mathrm{g} / \mathrm{l})$ & $32.9(31.2-34.6)$ & $38.0(36.8-39.1)$ & $0.00001^{*}$ \\
\hline Total globulin (g/l) & $55.7(52.2-59.2)$ & $40.0(37.8-42.2)$ & $0.00001^{*}$ \\
\hline Alpha-1 fraction (g/l) & $3.5(3.2-3.7)$ & $3.3(3.2-3.5)$ & $0.3^{*}$ \\
\hline Alpha-2 fraction ( $\mathrm{g} / \mathrm{l})$ & $9.7(9.1-10.3)$ & $9.2(8.9-9.5)$ & $0.1^{*}$ \\
\hline Total proteins (g/l) & $89.8(86.4-93.2)$ & $78.5(76.4-80.6)$ & $0.00001^{*}$ \\
\hline Beta fraction $(\mathrm{g} / \mathrm{l})$ & $9.4(8.8-10.0))$ & $8.8(8.3-9.2)$ & $0.1^{*}$ \\
\hline Gamma globulins (g/l) & $33.2(29.8-36.5)$ & $18.8(16.7-20.9)$ & $0.00001^{*}$ \\
\hline $\lg G(g / l)$ & $27.2(21.8-32.6)$ & $14.0(12.0-16.0)$ & $0.00001^{*}$ \\
\hline $\lg A(g / l)$ & $3.6(2.3-4.9)$ & $3.3(2.5-4.1)$ & $0.7^{*}$ \\
\hline $\lg M(g / l)$ & $1.9(1.4-2.5)$ & $1.7(0.6-2.8)$ & $0.8^{*}$ \\
\hline Beta-2-microglobulin (mg/l) & $5.9(3.8-7.9)$ & $4.3(2.4-6.2)$ & $0.3^{*}$ \\
\hline C-reactive protein (mg/l) & $88(-17.4-193)$ & $28(12.0-44.1)$ & $0.06^{*}$ \\
\hline \multicolumn{4}{|l|}{ SPEP patterns } \\
\hline Normal & $20 / 102(19 \%)$ & $71 / 228(31 \%)$ & $0.03^{\dagger \ddagger}$ \\
\hline Polyclonal gammopathy & $52 / 102(51 \%)$ & $42 / 228(18 \%)$ & $0.00001^{\dagger \ddagger}$ \\
\hline Oligoclonal bands & $34 / 102(33 \%)$ & $31 / 227(14 \%)$ & $0.00001^{\dagger \ddagger}$ \\
\hline Monoclonal gammopathy & $8 / 102(8 \%)$ & $37 / 228(16 \%)$ & $0.055^{\ddagger}$ \\
\hline Immunoparesis & $0 / 102(0 \%)$ & $\begin{array}{l}(11.4-21) \\
27 / 228(12 \%)\end{array}$ & $0.00001^{\dagger \ddagger}$ \\
\hline \multicolumn{4}{|c|}{$\begin{array}{l}p \text {-values in bold are significant at } \alpha=0.05 \text {. } \\
\text { Figures in parentheses are percentages where indicated, or otherwise represent the } 95 \% \text { confidence intervals. } \\
{ }^{*} \text {-test. } \\
\text { tChi-square test. } \\
\text { FFisher's exact test. }\end{array}$} \\
\hline
\end{tabular}


malignancies may increase as patients on highly active antiretroviral therapy (HAART) survive longer. ${ }^{5}$ Furthermore, the increase in $\mathrm{CD} 4 \mathrm{~T}$-cell numbers following HAART may promote B-cell maturation and differentiation to mature plasma cells, with possible emergence of neoplastic clones. Although monoclonal bands were not increased in HIV-positive patients in this study, vigilance is nevertheless prudent, since multiple myeloma may occur at a younger age ( $<40$ years) and the interpretation of SPEP patterns is complex in HIVpositive patients.

\section{REFERENCES}

1. McGowan JP, Shah SS, Small CB, et al. Relationship of serum immunoglobulin and IgG subclass levels to race, ethnicity and behavioral characteristics in HIV infection. Med Sci Monit 2006:12:CR11-16.

2. Rajkumar SV, Lacy MQ, Kyle RA. Monoclonal gammopathy of undetermined significance and smoldering multiple myeloma. Blood Rev 2007;21:255-265

3. Pantanowitz L, Dezube BJ. Editorial comment: multiple myeloma and HIV infection - causal or casual coincidence? AIDS Read 2003:13:386-387.

4. Stein L, Urban Ml, O'Connell D, et al. The spectrum of human immunodeficiency virus-associated cancers in a South African black population: results from a casecontrol study, 1995-2004. Int J Cancer 2008;122:2260-2265.

5. Yee TT, Murphy K, Johnson M, et al. Multiple myeloma and human immunodeficiency virus-1 (HIV-1) infection. Am J Hematol 2001;66:123-125.

6. Sitas F, Pacella-Norman $\mathrm{R}$, Carrara $\mathrm{H}$, et al. The spectrum of HIV-1 related cancers in South Africa. Int J Cancer 2000;88:489-492.

7. Kapsenberg LC, Cronje HS, van Jaarsveld H. Serum protein electrophoresis in HIV seropositive and seronegative pregnant women. Int J Gynaecol Obstet 2004;84:254-258 